\title{
Teaching English through Content-Based Learning Approach and Visual Presentation Method for Midwifery Students, Faculty of Medicine - Universitas Andalas
}

\author{
Ayendi ${ }^{1}$, Novalinda ${ }^{2}$ \\ \{ayendihardana@gmail.com ${ }^{1}$,novalinda@hum.unand.ac.id² \\ ${ }^{1,2}$ Faculty of Humanities, Universitas Andalas, Padang, Indonesia
}

\begin{abstract}
Classroom Action Research (CAR) is a researcher's personal intervention to produce improvements in the results of the Student Learning Process (PBM). The purpose of this CAR is to find out the extent to which the application of Content-Based Learning and Visual Presentation methods is able to improve various aspects related to the ability to communicate in English of 46 students in English class at the Midwifery Study Program at the Faculty of Medicine, Universitas Andalas. The findings show that in the process of undergoing two cycles of research implementation, it was gradually seen that the method with a more communicative approach was able to improve various aspects related to the ability to communicate in English. Obviously increased aspects include: increased mastery of midwifery vocabulary, understanding of midwifery content, courage in speaking, ability to interact with friends, motivation to learn, critical thinking, speaking fluency, grammatical understanding, and ability to make good PowerPoint. There are several obstacles in conducting research, especially in the first cycle, such as, the topics are less debatable, the learning approaches are less varied, the topics are too numerous and the group members discuss them little so participants who attend the presentation are a bit indifferent. However, the obstacles found in the first cycle can be overcome in the second cycle by the way the topics chosen in the second cycle are reduced and can be debated and there are quite a lot of group members discussing them.
\end{abstract}

Keywords: CAR, Content-Based Learning, Visual Presentation.

\section{Introduction}

The English subject is one of the compulsory courses in the Midwifery Study Program at the Faculty of Medicine, Andalas University, which is offered in the second semester. After taking this course, students are expected to be able to communicate in English about midwifery topics

Teaching materials used so far in the learning process prior to Classroom Action Research (PTK) in 2019 are more about discussing English grammar and relating it to texts that are suitable in the field of midwifery. Students do not discuss the content of midwifery texts, but only discuss about what the typical grammar is. The main reference books used in the PBM process are Walker, Elaine, and Steve Elsworth. 2011. Grammar Practice for Upper 
Intermediate Students with supporting books from other English Grammar textbooks. The learning method developed so far is in the form of discussions about grammar that have been set each week through group presentations and linking them with examples of sentences that are relevant to the grammar being discussed.

The assessment carried out in measuring student achievement has been applied so far in the form of presentation grades that discuss grammar, Mid-Semester exams, final semester exams, attendance, reading reports, and activeness. For mid and end of the semester exams are conducted in the form of written tests about understanding previous grammar topics using sentence data about the field of midwifery. As for the weight of the assessment are: Group presentation: 20\%, Attendance: 10\%, Activity: 10\%, Reading report assignment: $10 \%$, UTS: $25 \%$, and UAS: $25 \%$. The curriculum used is a curriculum based on CBC. The media used during the teaching and learning process uses books and power points.

Distribution of final grades of students in the previous semester is generally B- to B +. Based on the researchers' experience in teaching students of the class of 2018. The student lacks grammar mastery, resulting in his grades rarely getting A, and few who A-. PBM's too rigid process in class by limiting discussion presentations about grammar in class reduces student motivation to learn and actively speak in class, which impacts on students not being responsible for the success and activeness of the class. Based on the facts and phenomena above, the purpose of this research is to increase student motivation in communicating and learning English. Students are expected to be able to convey ideas and information they understand about the field of midwifery practiced in English

\section{Literature Review}

The first previous research was conducted by Junaidah, et al [1] from the FKSD Study Program of FKIP Untan with the research title "Improving Student Learning Outcomes Activity by Implementing a Realistic Mathematical Approach to Learning Mixed Computational Operations." The problem in this research is how to increase the activity of student learning outcomes by applying a realistic mathematical approach to learning mixed count operations. The method used in the writing is a descriptive method, the form is a class action and its nature is collaborative by following the procedure of writing class action. The subject of the writing was a mathematics teacher who numbered 29 people. The implementation of this class action is carried out in 2 cycles. The results obtained were the average score of the ability of teachers to make lesson plans in the first cycle of 3.95 and in the second cycle of 4 . The ability of teachers to carry out learning by applying a realistic mathematical approach in cycle I gained a score of 3.04 and in the second cycle 3.85 . Student learning activities in the first cycle scored $64.71 \%$ and in the second cycle scored $92.34 \%$. As for the learning outcomes obtained by students after participating in the learning of mixed count operations by applying a realistic mathematical approach in cycle I obtained an average score of 64.46 and in cycle II obtained an average score of 96.07.

The second previous research entitled "Improvement of Mathematics Learning Activities and Achievements Through Jigsaw Learning Model (CAR in Class VIII Odd Semester Semester 1 Colomadu Middle School Academic Year 2015/2016) conducted by Elham Ghozali [2] from the Mathematics Education Study Program, Faculty of Teacher Training and Education, Muhammadiyah Surakarta University. The purpose of his research is to improve student learning activities and outcomes through the Jigsaw learning model. This type of research is Classroom Action Research (CAR). The subjects of this study were the teachers and students of class VIII F of SMP N 1 Colomadu in the first semester, totaling 34 students. 
Data collection methods are carried out through interviews, observations, tests and documentation. Data analysis techniques using methods that include data collection, data reduction, data presentation, and drawing conclusions. The results of this study indicate an increase in mathematics learning activities and achievements. this can be seen through the following indicators: the ability to express ideas of thinking during teaching and learning activities there are 10 students $(29.40 \%)$ after the action became 26 students $(76.40 \%)$. the activeness of asking the teacher in teaching and learning activities there were 9 students $(26.40 \%)$ after the action became 28 students $(82 \%)$. the ability to discuss with study groups there were 13 students (38.20\%) after the action became 30 students $(88.20 \%)$. students who have the value of meeting the KKM $(\geq 75)$ there are 12 students $(35.20 \%)$ after the action becomes 29 students $(85.20 \%)$. The conclusion of this study is the jigsaw learning model can improve the activities and learning achievement of students in class VIII F SMP N 1 Colomadu Semester I.

\section{Methodology or Strategy of Achievement of Output}

The research subjects in this study were semester 2 students of the Midwifery Medicine Faculty Unand consisting of more than 40 students. The time of research is in the even semester 2018/2019, with the duration of the study for 1 semester with a total of 16 meetings. The research site is located in the Midwifery Campus in the Pondok City area of Padang

\section{A. Research Procedures and Steps}

Content-Based Learning based on is a study of language acquisition and subject matter. Instead of teaching languages separately, the target language becomes a medium where important information can be learned [3]. When students study content areas of interest, they are intrinsically motivated to learn content and language simultaneously. This method according to them is suitable for advanced students such as students.

The Visual Presentation is how images, in this case can also be points and lists of information items in the form of phrases (not in sentence form) that have an impact can improve presentation, communication, and delivery of messages that impress the audience. Using one relevant image can replace the whole text section and have more impact [4].

This research is a type of classroom action research. Mc Niff, et al [5] state that action research is a personal self intervention to produce improvements and have specific research problems. Furthermore, Gay and Airasian [6] state that action research is a type of practitioner research used to improve practitioners' practices. The act implies doing or changing something. Kemmis and Mc Taggart [7], involve four steps in this type of research, namely 1) formulating problems and planning actions, 2) monitoring actions and observations, 3) reflecting the results of observations, and 4) revising action plans. This action research was carried out in the form of a cycle. For one cycle, there are six topics.

Topics for the two cycles (16 meetings including introduction, preliminary, middle, and final examinations) planned are: for cycle one: Patient safety, the history of midwifery education in Indonesia, scope of midwifery practice, Midwife as the agent of change, the concept of midwifery management, How to become a midwife with integrity in her profession, lifelong learning, the paradigm of a midwifery led care, international challenges of the midwife in the future, ethics in midwifery, good communication and service for patients, midwife duties and responsibility, midwifery skills, midwife as a profession, the role of midwives in the communities, and the concept of basic midwifery. 
Cycle 1

1. Planning

A. Make or find three topics related to midwifery

B. Design a group consisting of two students

C. Determine the role of the group, such as: the role of group leader, role secretary, and the role of group members.

D. Establish rules during the discussion

E. Prepare research instruments.

F. Collaborate with the accompanying lecturer

G. Make an agenda before each group meeting.

- Step 1: Students read references about related topics at home

- Step 2: students make a reading summary

- Step 3: students make a PowerPoint in visual form no higher than the language unit of the phrase (not sentences) with the relevant background image

The role of group leader

- Leads the group carrying out presentations

- Does presentation

- Ensures equal participation from all members

- Maintains the dynamics of discussion

- Keeps time

- Ensures group members focus on the given task

- Answers the question

The role of the secretary

- DoesPresentation

- Makes notes of who asked and who gave answers

- Makes discussion reports

The role of group members

- DoPresentation

- Record points raised by students

- Participate actively in group discussions.

- Hear the contribution of each group

Role of discussion participants

- Make questions open

- Help answer questions from other participants

- Make a reading report

The role of the research lecturer

- Facilitates group interaction

- Considers how to improve student abilities

- Listens carefully

- Asks

- Monitors student progress and appearance 


\section{Acting}

Class activities are carried out according to the plan. During the group meeting, it is certain that the discussion stage follows the group presentation, participants ask questions, and the answers are not answered directly by the group but by other discussion participants. During the discussion the lecturer stimulates the conversation by asking open-ended questions (for example how ...? What ... Why ...? Where ...? That will allow the group to explore the material in more depth.

\section{Observing}

A. The researcher monitors the group learning activities by walking or sitting in the back seat of the class.

B. Collaborators observe researchers during the discussion/presentation process.

C. Collaborators observe, take notes, and record spoken English activities during the learning process.

D. Researchers and collaborators evaluate activities using instruments evaluation that has been prepared.

\section{Evaluating}

At the end of the first cycle, researchers and collaborators analyze data collected from observation sheets/checklists, interviews, and speech tests to make conclusions about weaknesses/problems. And progress / was found in cycle one. For aspects of weakness, researchers try to improve it, and for aspects of success or strength, researchers continue to use it for the next cycle.

\section{a. Development of student assessments}

Student assessments come from several categories, namely the value of soft skills, hard skills, processes, and self-assessment. First, the value of soft skills is taken from attitude, cooperation, presentation readiness, and leadership. Hard skill scores are taken from appearance, and the ability to speak during discussions and examinations. The value of the process is taken from the activeness and presence of students in class. The self-assessment scores are taken during the mid and final semester exams.

\section{b. CAR parameters}

The assessment of speaking ability is based on Hughes' speech test rubric [8]. There are five rubric components that are sorted by the weight of the assessment weight, namely: 1) grammar, 2) vocabulary, 3) fluency, 4) understanding, and 5) accent. Each indicator has 6 levels of proficiency.

The final component of student assessment consists of the value of soft skills, hard skills and processes.

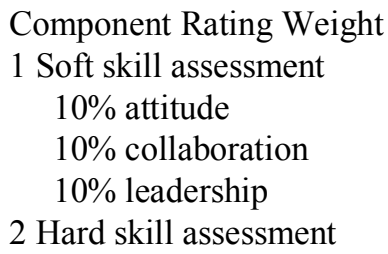




\author{
$10 \%$ presentation appearance \\ $10 \%$ Understanding topics and grammar \\ $10 \%$ oral mid test \\ $10 \%$ oral final test \\ 3 Assessment process \\ $10 \%$ activity \\ $10 \%$ attendance \\ 4 Self-assessment $10 \%$
}

\title{
4. Results and Discussion
}

On January 20, 2019 researchers discussed the implementation of CAR with collaborators. Then on January 29, 2019, research tools and instruments were provided. Then on February 1, 2019, researchers set lecture contracts, explained lecture procedures, and divided groups with students at the first class meeting. On February 8, 2019 group presentation 1: The Concept of Basic Midwifery and group presentation 2: History of Midwife Education. On February 15, 2019, group presentation 3: Midwives as Agents of Change and group presentation 4; Healthy Sickness Factors. On February 22, 2019, group presentation 5: The Concept of Midwifery Management and group presentation 6: Antenatal Care. On March 1, 2019, group presentation 7: Long Live Learning and group presentation 8: Needs For Rest and Sleep. On March 15, 2019, group presentation 9: Social Marketing in Midwifery Service and group presentation 10: International Challenge for Midwives in The Future. On March 22, 2019, group presentation 11: Wound Types and Healing and group presentation 12: Communication Skills. On 8 March 2019 Midterm Exams.

From observations by a collaborator in the learning process in the first cycle, presenter students were still involved in general, still reading PowerPoint (PPT) material and material on mobile phones even though they were reminded not to read, but explained the points. The material in PPT also still uses long sentences. Only a few students have made it into points and that too isn't parallel. The class situation is still a bit less calm, especially if the presenter is reading and the topic is not interesting. They are busy with their own activities. At the beginning of the class students present their topics and at the end of the presentation there are groups who explain grammar and some who don't. After that followed by a discussion of topics and grammar.

A small number of students are quite active in asking and answering questions for discussion questions and that person is all. Lecturers always motivate students to be active. Rating with range 1 to.d. 6 shows the average accent value for student speaking practice is 4 , fluency score is 3, grammar value is 3, comprehension value is 3, and vocabulary value is 4 . As for the average written test score for mid-semester is B + .

From a total of 46 students, the results of interviews with students after the midterm exams for the first cycle of PTK which consisted of 6 meetings showed: 42 students expressed their ability to improve in various ways. 22 students expressed their ability or activeness to speak (public speaking) and asked them without seeing the text increase. 1 student stated critical thinking increased. 1 student stated that he was more able to make a good PPT. 17 students stated their grammar understanding increased. 20 students stated the addition of their vocabulary in the field of midwifery. 7 students said their pronunciation increased. 11 students expressed their understanding of the topic or field of midwifery increased. 19 students expressed their confidence or courage in speaking increased. 6 students expressed their motivation to learn increased. 2 students stated their ability to interact or cooperate with other 
students increased. 3 people said their fluency had increased. 2 students stated that the lecturer was close to the students.

The weaknesses felt by students on conducting lectures from the results of the interview are as follows: 9 students stated that they did not understand the grammar explained by students or their own friends who were presenting because they were focused on content. 18 students said they felt sleepy and bored or that their other friends were indifferent to the presentations made by their friends. 2 students stated when the presentation was too focused or read the text and did not pay attention to the audience. 5 students stated the material was not directed. 1 student stated that his grammar did not increase. 1 student stated that the presentation made him confused because he was not used to it. 8 students stated that they did not understand the content due to lack of vocabulary. 1 student stated a lack of campus facilities. 1 person said the voice of the lecturer softly. 1 student stated the group appeared as it was. 1 person stated lecture in sleepy lesson hours

How can all aspects of the language improvements in the next lecture cycle, from the results of interviews with students they gave answers: 6 students stated that they should explain the grammar in full and in the explanation by the lecturer, and write it in front of the class. The lecturer said he could justify the grammar of students when presenting. 2 students suggest other students understand the topic presented. 5 students suggested that the group display videos, interspersed with quizzes or games. 2 students suggested the topic be reduced and the number of group members 4 to 6 people. 1 student expressed satisfaction with the existence of a summary assignment to increase understanding and increase their vocabulary. 1 student suggests not to be boring and other students indifferent so he suggests the same material for one week is discussed by each group, after that only a big debate or discussion session and the questioner is given an assessment point

Based on the results of planning, implementation, monitoring, and evaluation in the first cycle of CAR, the researcher concluded that PBM activities had not been maximally successful. There are still shortcomings, especially in terms of the composition of ppt, reading in presentations, some of them indifferent when presenting friends, lacking understanding of grammar so it is often wrong when speaking.

Therefore, in cycle 2 to 7 meetings after the midterm to the final exam, researchers together with a collaborator create strategies and planning to cover the PBM weaknesses in the first cycle obtained based on observations, interviews, and grades. For this reason, in the second cycle, the research lecturer made more stringent regulations regarding ppt composition and did not read but explained the points of his presentation. Then choose the topic of a more interesting presentation about the day-to-day field practice that is up to date that can make students interested to know it and cause arguments in the discussion, rather than on topics that smelled of theory. If in the first cycle at each meeting there are 2 groups with 2 topics, 1 for each of them, then in this cycle 2 only presents and discusses 1 topic. So they can compete for arguments for 1 topic rather than conveying their respective topics. For grammar, the lecturer explains and the student prepares a quiz with relevant questions and answers, and if possible the group provides a light gift in the form of small cakes or sweets. For active students who ask and answer notified they will be given an additional value, where the value of the answer is higher than the one asking.

Implementation of lectures in the second cycle in the sequence are: on April 5, 2019, group presentations 13 and 14: with the topic Midwife Independent Practice. On April 12, 2019, group presentations 15 and 16 with the topic Code of Ethics. On April 26, 2019, group presentations 17 and 18 with the topic Role of Midwife in Health Care. On May 3, 2019, group presentations 19 and 20 with the topic The Situation of Midwives in Indonesia. On May 
10, 2019 group presentation 20-21 with the topic Patient Safety. On May 17, 2019, group presentations 23 and 24 covered the topic Scopes of Midwifery Practice. On May 24, 2019, group presentations 24 and 25 with the topic Midwife as a Profession. Finally, on June 7, 2010 , the final semester exams

Of the total 46 students with students before the end of the semester exams for the second cycle of this PTK consisting of 7 meetings, from the results of the general interview simultaneously to students before continuing the final exam in the answer sheet, without leading opinions to provide more specific answers. Like: Do you feel an improvement in various things after attending this lecture in the second cycle? In what ways were the improvements? And what weaknesses do you feel?

The results of the self-assessment in the second cycle showed: 46 students stated that they gained capabilities from various things. 38 students expressed their ability or activity to speak (public speaking) and asked them without seeing the text increase. 23 students stated that their critical thinking increased. 27 students said they were more able to make good PPT. 31 students stated that their grammar understanding increased. 34 students stated the addition of their vocabulary in the field of midwifery. 27 students said their pronunciation increased. 35 students expressed their understanding of the topic or field of midwifery increased. 30 students expressed their confidence or courage in speaking increased. 32 students stated their motivation to learn increased. 29 students stated their ability to interact or cooperate with other students increased. 24 people said their fluency had increased.

From observations by collaborators on the learning process involved presenters in general no longer read PPT material and material on mobile phones because they were reminded not to read, but explained the points. The material in PPT also generally does not use long sentences, but has made it into points or phrases but there is still a little parallel, the class situation is quite calm because the topic is interesting and new to them especially if the presenter explains in clear and fluent English. At the beginning of the class students present their topics and at the end of the presentation the lecturer explains the grammar and is followed by a grammar quiz by the student's presentation. After that followed by a discussion of topics and grammar. Most students are quite active in asking and answering questions for discussion questions and the people have varied because of the promise of additional or good grades. Lecturers always motivate students to be active. Ratings range from 1 to d. 6 shows the accent value for speaking practice of students in the second cycle the average is 5 , the fluency value is 4 , the grammar value is 4 , the comprehension value is 5 , and the vocabulary value is 5 . As for the average written test scores for mid-semester are A- and A.

\section{Conclusion}

This Classroom Action Research (CAR) is a researcher's personal intervention to produce improvements in the results of the Student Learning Process (PBM) in English Subjects at the Midwifery Study Program at the Faculty of Medicine, Andalas University. In the process of undergoing two cycles of research implementation, Content-Based Learning and Visual Presentation methods gradually appear with a more communicative approach that can improve various aspects related to the ability to communicate in English. Obviously increased aspects include: increased mastery of midwifery vocabulary, understanding of midwifery content, courage in speaking, ability to interact with friends, motivation to learn, critical thinking, speaking fluency, grammatical understanding, and ability to make Power Good point. There are several obstacles in conducting research, especially in the first cycle, such as, the topics are less debatable, the learning approaches are less varied, the topics are too numerous and the 
group members discuss them little so participants who attend the presentation are a bit indifferent. However, the obstacles found in the first cycle can be overcome in the second cycle by the way the topics chosen in the second cycle are reduced and can be debated and there are quite a lot of group members discussing them.

\section{References}

[1] Junaidah, et al."Peningkatan Aktivitas Hasil Belajar Siswa dengan Menerapkan Pendekatan Matematika Realistik Pembelajaran Operasi Hitung Campuran."

[2] Ghozali, Elham. "Peningkatan Aktivitas dan Prestasi Belajar Matematika Melalui Model Pembelajaran Jigsaw (PTK pada Siswa Kelas VIII Semester Gasal SMP Negeri 1 Colomadu Tahun Ajaran 2015/2016). Program Studi Pendidikan Matematika, Fakultas Keguruan dan Ilmu Pendidikan, Universitas Muhammadiyah Surakarta.

[3] Brown, Douglas. Teaching by Principles: An Interactive Approach to Language Pedagogy

[4] Keim et al., 2006 Keim, D.A.; Mansmann, F. and Schneidewind, J. and Ziegler, H., Challenges in Visual Data Analysis, Proceedings of Information Visualization (IV 2006), IEEE, p. 9-16, 2006.

[5] Mc Niff. J., et al. 1996. You and Your Action Research Project. New York: Hyde Publications

[6] Gay and Arasian Peter. 2000. Educational Research: Competencies for Analysis and Application. Tokyo: Prentice Hall, Inc.

[7] Kemmis, S \& McTaggart, R. 1988. The Action Research Planner. Victoria, Australia: Deakin University.

[8] Hughes, Arthur. 1983. Testing for Language: Cambridge University Press 